\title{
The Regulation of Heme Turnover and Carbon Monoxide Biosynthesis in Cultured Primary Rat Olfactory Receptor Neurons
}

\author{
Tatsuya Ingi, ${ }^{1}$ George Chiang, ${ }^{1}$ and Gabriele V. Ronnett ${ }^{1,2}$ \\ Departments of ${ }^{1}$ Neuroscience and ${ }^{2}$ Neurology, The Johns Hopkins University School of Medicine, \\ Baltimore, Maryland 21205
}

Heme oxygenase $(\mathrm{HO})$ converts heme to carbon monoxide (CO) and biliverdin, which is metabolized rapidly to bilirubin. $\mathrm{CO}$ is implicated as an intercellular messenger, whereas bilirubin could function as an antioxidant. These cellular functions differ significantly from those of $\mathrm{HO}$ in peripheral tissues, in which it degrades heme from senescent erythrocytes, suggesting that the regulation of $\mathrm{HO}$ may differ in neurons from that in other tissues. Among neurons, olfactory receptor neurons have the highest level of $\mathrm{HO}$ activity. Metabolic labeling with $\left[2-{ }^{14} \mathrm{C}\right]$ glycine or $\delta-\left[{ }^{3} \mathrm{H}\right]$ aminolevulinic acid $\left(\left[{ }^{3} \mathrm{H}\right] \mathrm{ALA}\right)$ was used to investigate heme metabolic turnover and $\mathrm{CO}$ biosynthesis in primary cultures of olfactory receptor neurons. The production rates of heme precursors and metabolites from $\left[{ }^{14} \mathrm{C}\right]$ glycine over $6 \mathrm{hr}$ were (in pmol/mg protein): 100 for ALA, 8.2 for heme, and 2.9 for $\mathrm{CO}$. Taking into account endogenous heme content, the amount of total $\mathrm{CO}$ production was determined to be 1.6 $\mathrm{nmol} / \mathrm{mg}$ protein per $6 \mathrm{hr}$. Heme biosynthesis usually is subject to end-product negative feedback at the level of ALA synthase. However, metabolic control in these neurons is different. Both heme concentration (heme formation) and $\mathrm{HO}$ activity (heme degradation) were enhanced significantly during immature stage of neuronal differentiation in culture. Neuronal maturation, which is accelerated by transforming growth factor- $\beta 2$ (TGF$\beta 2$ ), suppressed the activities of both heme biosynthesis and degradation. To explore the physiological importance of this endogenous production of $\mathrm{CO}$, we examined the potency of $\mathrm{CO}$ as a soluble guanylyl cyclase activator. Exogenous $\mathrm{CO}$ (10-30 $\mu \mathrm{M})$, comparable to endogenous $\mathrm{CO}$ production, significantly activated guanylyl cyclase, suggesting that $\mathrm{HO}$ activity may regulate cGMP levels in the nervous system.

Key words: heme; metabolic turnover; heme oxygenase; carbon monoxide; guanylyl cyclase; olfactory receptor neuron
Recent interest has focused on the role of $\mathrm{CO}$ as a member of the class of diffusible messenger molecules involved in intercellular neuronal communication (Stevens and Wang, 1993; Zhuo et al., 1993; Leinders-Zufall et al., 1995; Nathanson et al., 1995; Prabhakar et al., 1995; Ingi et al., 1996). CO is generated by the action of heme oxygenase ( $\mathrm{HO})$, which degrades heme to $\mathrm{CO}$ and biliverdin, which is then converted to bilirubin. Because $\mathrm{CO}$ shares some of the chemical and biological properties of nitric oxide (NO), it is able to bind to the iron in heme associated with soluble guanylyl cyclase, leading to activation of the enzyme (Brüne and Ullrich, 1987; Furchgott and Jothianandan, 1991; Kharitonov et al., 1995). A role for CO as a physiological messenger was suggested in long-term potentiation in hippocampus (Stevens and Wang, 1993; Zhuo et al., 1993), chemosensors of the carotid body (Prabhakar et al., 1995), regulation of cyclic nucleotide-gated channels in olfactory receptor neurons (Leinders-Zufall et al., 1995), and regulation of Na, K-ATPase in cerebellum (Nathanson et al., 1995). In addition, bilirubin has been proposed to function as a neuronal antioxidant. These roles differ substantially from that of heme metabolism in peripheral tissues (in which it acts to degrade heme from senescent blood

Received March 18, 1996; revised June 17, 1996; accepted June 28, 1996.

T.I. is a Postdoctoral Fellow for Research Abroad, supported by Japan Society for the Promotion of Science. G.V.R. is supported by a National Institutes of Health grant, a McKnight Scholars Award, and grants from the Whitehall Foundation, the Develbiss Fund, and the W. M. Keck Foundation. We thank M. Angelyn Bethel for technical assistance and Lana Kramer for manuscript preparation.

Correspondence should be addressed to Dr. Gabriele V. Ronnett, Department of Neuroscience, The Johns Hopkins University School of Medicine, 725 North Wolfe Street, Baltimore, MD 21205.

Copyright (C) 1996 Society for Neuroscience $0270-6474 / 96 / 165621-08 \$ 05.00 / 0$ cells), suggesting that the regulation of $\mathrm{HO}$ may be different in brain, as well. HO consists of two homologous isozymes (Maines, 1988). Whereas type 1 (HO-1) is induced by heme and is most abundant in the spleen and liver, where it is responsible for destruction of heme from senescent red blood cells (Cruse and Maines, 1988), type 2 (HO-2) is the constitutive form expressed at high levels in the brain. The colocalization of ALA synthase (ALAS) with HO-2 in the brain indicates that the machinery for porphyrin turnover and CO biosynthesis occurs together (Verma et al., 1993).

Cultures of olfactory receptor neurons have been used to investigate the relationship of $\mathrm{CO}$ to cGMP levels, because these cells have high levels of $\mathrm{HO}$ activity but no NOS activity (Verma et al., 1993; Ingi and Ronnett, 1995; Leinders-Zufall et al., 1995). Thus, the relevance of $\mathrm{CO}$ as a mediator of cGMP can be studied in this cell in the absence of NO, a more potent activator of soluble guanylyl cyclase, which could confound results. Inhibition of $\mathrm{HO}$ activity and $\mathrm{CO}$ production significantly lowered endogenous cGMP levels in these cells (Verma et al., 1993; Ingi and Ronnett, 1995). These lines of evidence suggest that CO may function as an endogenous regulator of cGMP levels.

In this study, metabolic labeling of heme was used to investigate the regulatory mechanism of porphyrin turnover and $\mathrm{CO}$ production caused by heme degradation under physiological conditions in primary cultures of olfactory receptor neurons. With this approach, we directly demonstrate the significant level of both endogenous heme production and turnover in neurons, the neuronal regulatory mechanism of heme turnover, and the involvement of heme turnover in neuronal differentiation. On the basis of these results, we have gone on to demonstrate that addition of 
exogenous $\mathrm{CO}$ at the determined physiological concentrations can augment cGMP production. Our observations suggest the physiological relevance of heme turnover in the nervous system and the role of $\mathrm{CO}$ as a cGMP regulator. These biochemical data provide a first step toward further studies aimed at the physiological relationship of $\mathrm{CO}$ production with odors stimulation and other neurotransmitters, including their possible involvement in olfactory neuronal development and signal transduction.

\section{MATERIALS AND METHODS}

Materials. $\left[2-{ }^{14} \mathrm{C}\right]$-glycine $(57 \mathrm{mCi} / \mathrm{mmol})$ was purchased from ICN Biomedicals (Cleveland, $\mathrm{OH})$, and $\delta$ - $\left[3,5-{ }^{3} \mathrm{H}\right]$ aminolevulinic acid $(1.87 \mathrm{Ci} /$ mmol) was obtained from DuPont NEN Radiochemicals (Wilmington, $\mathrm{DE})$. $\mathrm{Zn}$ protoporphyrin 9 (ZnPP9) was obtained from Porphyrin Products.

Assay of heme oxygenase activity. Microsomes were prepared from each tissue as previously described (Schacter, 1978). Heme oxygenase activity was measured by the method of Tenhunen et al. (1970a). Briefly, the 1.0 $\mathrm{ml}$ reaction mixture contained $0.1 \mathrm{M}$ potassium phosphate buffer $(\mathrm{pH} 7.4)$, microsomes ( $1 \mathrm{mg}$ of protein), $17 \mu \mathrm{M}$ hemin, $180 \mu \mathrm{M} \mathrm{NADPH}$, and purified biliverdin reductase (step 3,1 $\mathrm{mg}$ of protein) (Tenhunen et al., $1970 \mathrm{~b}$ ). The reaction was performed for $10 \mathrm{~min}$ at $37^{\circ} \mathrm{C}$. Blank assays were conducted in the absence of NADPH. The rate of bilirubin formation was calculated from the rate of increase in absorbance $(468 \mathrm{~nm})$. The extinction coefficient, obtained with standards in the reaction mixture, was $13.9 \mathrm{~mm}^{-1} \mathrm{~cm}^{-1}$.

Cell culture. Primary cultures of olfactory receptor neurons were prepared from neonatal rats, as previously described (Ronnett et al., 1991), and cultured for $5 \mathrm{~d}$ in 24 well plates, 6 well plates, $9 \mathrm{~cm}$ dishes (for extraction assays and RT-PCR), or slide flasks (for ${ }^{14} \mathrm{CO}$ assay), with modified Eagle's medium containing D-valine (MDV; Life Technologies, Grand Island, NY) containing $15 \%$ (v/v) dialyzed fetal calf serum (Life Technologies), gentamycin, kanamycin, nerve growth factor (Collaborative Research, Bedford, MA), and cytosine arabinoside. These cultures contained $<5 \%$ glial contaminants (Ronnett et al., 1991).

Cellular uptakes of $\left[{ }^{14} \mathrm{C}\right]$ glycine and $\left[{ }^{3} \mathrm{H}\right] A L A$. Olfactory receptor neuron cultures in 24 well plates were incubated with $2 \mu \mathrm{Ci} / \mathrm{ml}$ of $\left[{ }^{14} \mathrm{C}\right]$ glycine or 40 $\mu \mathrm{Ci} / \mathrm{ml}$ of $\left[{ }^{3} \mathrm{H}\right] \mathrm{ALA}$ for $6 \mathrm{hr}$. At indicated time intervals after the addition of radiolabeled materials, cells were transferred into eppendorfs and washed three times in ice-cold PBS, and the cellular radioactivity was counted.

Extraction and quantitation of labeled ALA. This procedure was performed essentially as described (Ebert et al., 1970; Gardner et al., 1991). Briefly, cultures were incubated with $\left[{ }^{14} \mathrm{C}\right]$ glycine as described above. After stopping the incubation with $\left[{ }^{14} \mathrm{C}\right]$ glycine by addition of ice-cold PBS and rapid centrifugation, the cell pellets were washed three times by centrifugation and lysed in $200 \mu \mathrm{l}$ of $0.2 \%$ (w/v) aqueous sodium deoxycholate. The solubilized protein was precipitated by addition of $50 \%(\mathrm{w} / \mathrm{v})$ trichloroacetic acid (TCA) to a final concentration of $5 \%(\mathrm{w} / \mathrm{v})$. ALA was isolated by ion exchange chromatography on columns $(0.5 \mathrm{ml}$ gel bed) of Dowex resin (type 50W $\times 8$, mesh size 200-400; Sigma, St. Louis, MO) that had been prepared by twice heating in $2 \mathrm{M} \mathrm{NaOH}$ to $50^{\circ} \mathrm{C}$ and washing in distilled water. Before use, the stored resin was equilibrated in $0.05 \mathrm{~m}$ sodium acetate, $\mathrm{pH}$ 3.9. TCA supernatants containing ALA were applied to Dowex columns that then were washed with $30 \mathrm{ml}$ of acetate buffer to remove the unconverted glycine label and other radiolabeled material. Then ALA was eluted with a pulse of $600 \mu \mathrm{l}$ of $0.25 \mathrm{M}$ sodium phosphate buffer, $\mathrm{pH}$ 6.8. The eluates were assayed for ${ }^{14} \mathrm{C}$-radioactivity in a scintillation counter.

Extraction and quantitation of heme. The extraction of heme from the various tissues and ${ }^{14} \mathrm{C}$-labeled culture was performed essentially as described (Ponka and Schulman, 1985). Briefly, cultures in 6 well plates or 10 $\mathrm{cm}$ dishes were incubated with $\left[{ }^{14} \mathrm{C}\right]$ glycine as described. Cells were washed twice with ice-cold PBS, lysed with $500 \mu \mathrm{l}$ of distilled water, and kept frozen overnight. After the samples were thawed, heme was extracted from $500 \mu \mathrm{l}$ of these cell homogenates by vigorously mixing with $1 \mathrm{ml}$ of ethyl acetateglacial acetic acid (3:1). One additional extraction was done with $1 \mathrm{ml}$ of the same reagent, and the extracts then were pooled. The extracts were washed three times with $1 \mathrm{ml}$ of $0.3 \%$ sodium acetate and twice with $2 \mathrm{ml}$ of $1.5 \mathrm{~N}$ $\mathrm{HCl}$. The total heme content in the extracts was quantitated fluorometrically by the method of Morrison, as described (Sassa et al., 1975). Samples were added to $2 \mathrm{M}$ oxalic acid and heated at $100^{\circ} \mathrm{C}$ for $30 \mathrm{~min}$. After cooling, the fluorescence was measured at $662 \mathrm{~nm}$ during excitation at $400 \mathrm{~nm}$ with a Perkin-Elmer LS50 luminescence spectrometer. For the measurement of
${ }^{14} \mathrm{C}$-labeled heme, heme crystallizations were performed by the method of Labbe and Nishida (1957) with modification (Falk, 1975). $\left[{ }^{14} \mathrm{C}\right]$ heme was crystallized in the presence of carrier heme, and the radioactivity of this material was counted.

Extraction and quantitation of ${ }^{3} \mathrm{H}$-labeled heme and bile pigment. The cultures plated in $10 \mathrm{~cm}$ dishes were incubated with $40 \mu \mathrm{Ci} / \mathrm{ml}\left[{ }^{3} \mathrm{H}\right]$ ALA. At $6 \mathrm{hr}$ after the addition of $\left[{ }^{3} \mathrm{H}\right] \mathrm{ALA}$, cells were scraped into $1 \mathrm{ml}$ of PBS. After addition of $0.1 \mathrm{ml}$ of carrier pigment in the form of normal bile containing $\sim 15 \mathrm{mg} / \mathrm{dl}$ total bilirubin, mono- and diglucuronide conjugates were converted quantitatively to the corresponding methyl esters by alkaline methanolysis (Blanckaert, 1980). Heme, unconjugated bilirubin, and the bilirubin methyl esters were extracted into chloroform (Blanckaert, 1980), and the solution was reduced to dryness under nitrogen. The residue was dissolved in $30 \mathrm{ml}$ of chloroform/methanol (1:1) and applied to thin-layer plates (Silica Gel IB2, J.T. Baker, Phillipsburg, NJ) that were developed immediately in one of two different solvent systems. Chloroform/methanol/acetic acid (97:2:1) was used for separation of bilirubin and its mono- and dimethyl esters. In this system, heme migrates $<1 \mathrm{~cm}$. To separate heme from the origin, a second system consisting of chloroform/methanol/water/acetic acid (40:20:4:1) was used. Under these conditions, heme migrates with $R_{\mathrm{F}}=0.65$, whereas bilirubin and its methyl esters migrate in a single band with $R_{\mathrm{F}}=0.9$.

${ }^{14} \mathrm{CO}$ measurement. On each culture day, cultures in slide flasks were preincubated with $5 \mu \mathrm{Ci}$ of $\left[2-{ }^{14} \mathrm{C}\right]$ glycine for various times, and the radioactivity incorporated into ${ }^{14} \mathrm{CO}$ was measured as described (Lincoln et al., 1989). Briefly, the gases from cultured flasks were drawn through the following series of traps: ethanolamine-methanol (trap for $\mathrm{CO}_{2}$ ), $\mathrm{H}_{2} \mathrm{SO}_{4}, \mathrm{CaCl}_{2}$, heated Hopcalite, and ethanolamine-methanol (trap for $\mathrm{CO}) .{ }^{14} \mathrm{CO}$ was converted to ${ }^{14} \mathrm{CO}_{2}$ by hopcalite and collected in the second ethanolamine-methanol trap. Each trapping solution was counted. No radioactivity over background $(30 \mathrm{cpm})$ was detected in the CO trap when Hopcalite was removed from the series of traps. When inhibitors were used, cultures were incubated with $\left[{ }^{14} \mathrm{C}\right]$ glycine in the presence of ZnPP9 at the indicated concentrations for $6 \mathrm{hr}$. Then the gases were drawn from the flasks.

Reverse transcriptase-PCR (RT-PCR). Primary cultures of olfactory receptor neurons were plated as described, except that cells were plated in a medium that did not contain exogenous growth factors. After cell plating $(\sim 6 \mathrm{hr})$, the feeding medium was replaced with fresh medium with or without $10 \mathrm{ng} / \mathrm{ml}$ TGF- $\beta 2$. Cultures were maintained for $1-5 \mathrm{~d}$, at which time $\left[{ }^{14} \mathrm{C}\right]$ heme production and $\mathrm{HO}$ activity were measured as previously described to determine the effects of neuronal maturation and TGF- $\beta 2$. On day 3, poly(A) RNA was prepared from cultured olfactory receptor neurons. cDNA was synthesized in a $50 \mu \mathrm{l}$ reaction using $1 \mu \mathrm{g}$ of poly(A) RNA. The RNA mixed with $100 \mathrm{ng}$ oligo(dT) primer was denatured for $10 \mathrm{~min}$ at $70^{\circ} \mathrm{C}$ and cooled to $37^{\circ} \mathrm{C}$. Reverse transcription was performed at $37^{\circ} \mathrm{C}$ for $1 \mathrm{hr}$ after addition of $10 \mu \mathrm{l}$ of $5 \times$ reverse transcription buffer (Bethesda Research Labs, Bethesda, MD), $5 \mu$ l of 0.1 M DTT, $2 \mu \mathrm{l}$ of $2.5 \mathrm{~mm}$ dNTPs, $20 \mathrm{U}$ of RNasin, and $2 \mu \mathrm{l}$ of MMLV reverse transcriptase (Superscript; Bethesda Research Labs). After firststrand cDNA synthesis, HO-2 and $\beta$-actin PCR products were generated from these cDNAs. cDNA $(5 \mu \mathrm{l})$ was used as a template in subsequent $50-\mu \mathrm{l}$-reaction volumes. PCR amplifications were performed for 30 cycles with the following specific oligo primers $(0.5 \mu \mathrm{M})$ : P16 and P17 for HO-2, and Act- 5 and Act- 3 for $\beta$-actin. Under the condition used, PCR products increased linearly between $28-33$ cycles.

Oligonucleotides used as PCR primers were synthesized from the following positions in the cDNAs:

HO-2 (Rotenberg and Maines, 1988):

P16 = 5'-CACTTGGGATAGGATGCAAACA AC-3' (from 984 to 961 on cDNA)

P17 = 5' -TTTGAATGAGCCAAGGACCGAAGTG-3' ( -49 to -25 on cDNA).

The predicted size of PCR products with P16 and P17 is 1033 bp. $\beta$-actin (Nudel et al., 1983):

Act-5 = 5'-ATGGATGACGATATCGCTGCGCTC-3' (from 1242 to 1265 on gene)

Act-3 = 5'-GGCCAGGATAGAGCCACCAATCCA-3' (from 3045 to 3022 on gene).

The predicted size of PCR products with Act-5 and Act-3 is 1042 bp.

Guanylyl cyclase activity assay. The brain was excised from adults rats and immediately placed in ice-cold $50 \mathrm{~mm}$ Tris- $\mathrm{HCl}, \mathrm{pH}$ 7.4, containing 1 mM DTT, finely minced, washed twice with this buffer, and homogenized. The homogenate was centrifuged for $10 \mathrm{~min}$ at $10,000 \times \mathrm{g}$, and the supernatant was ultracentrifuged for $60 \mathrm{~min}$ at $105,000 \times \mathrm{g}$. Guanylyl 
Table 1. Heme content and microsomal HO enzymatic activity of various kinds of tissues

\begin{tabular}{lcc} 
Tissue & $\begin{array}{l}\text { Heme content } \\
(\text { nmol/mg protein })^{a}\end{array}$ & $\begin{array}{l}\text { HO enzymatic activity } \\
\left.\text { (pmol bilirubin/mg }^{\text {protein/min) }}\right)^{b}\end{array}$ \\
\hline Spleen & $13 \pm 0.5$ & $1430 \pm 20$ \\
Liver & $1.0 \pm 0.02$ & $290 \pm 4$ \\
Whole brain & $1.3 \pm 0.1$ & $280 \pm 5$ \\
Olfactory epithelium & $1.5 \pm 0.08$ & $425 \pm 5$ \\
Cerebellum & $1.5 \pm 0.04$ & $310 \pm 6$ \\
\hline
\end{tabular}

${ }^{a}$ The heme concentration was determined by fluorescence spectrophotometer.

${ }^{b}$ Enzymatic activity was assayed under standard conditions as described in Materials and Methods. Formation of bilirubin was measured spectrophotometrically and expressed as pmol of bilirubin/mg protein $/ \mathrm{min}$.

Data are presented as the mean of two to three independent experimental determinations \pm SEM.

cyclase activity in the obtained cytosolic fraction $(0.75 \mathrm{mg}$ of protein per assay tube) was determined by incubation for $10 \mathrm{~min}$ at $37^{\circ} \mathrm{C}$ in the presence of $50 \mathrm{~mm}$ Tris- $\mathrm{HCl}$, pH 7.4, containing (in mM): 1 DTT, 1 GTP, and $5 \mathrm{MgCl}_{2}$. The incubation was terminated with a 0.3 volume of $18 \%$ TCA, and cGMP was quantitated by radioimmunoassay (Amersham, Arlington Heights, IL). The indicated concentrations of exogenous CO were achieved by adding a series of diluted $\mathrm{CO}$-containing buffers. To make $\mathrm{CO}$-equilibrated buffer, Tris- $\mathrm{HCl}$ buffer was bubbled with $100 \%$ $\mathrm{CO}$ gas for $1 \mathrm{~min}$.

\section{RESULTS}

\section{Comparison of heme and $\mathrm{HO}$ in peripheral and neural tissues}

Throughout the body, high levels of $\mathrm{HO}$ activity are distributed in the spleen and liver, where HO is responsible for the destruction of heme from senescent red blood cells. To evaluate the activity of heme turnover in the nervous system, we determined the cellular concentrations of heme and microsomal HO enzymatic activities in tissue preparations from spleen, liver, brain, cerebellum, and olfactory epithelium (Table 1). Spleen displayed the highest values for both the level of heme and HO activity. In whole brain, $\mathrm{HO}$ activity and heme levels were similar to those of liver. These values for $\mathrm{HO}$ activities obtained by this assay resemble those previously reported by others (Maines, 1988). Olfactory neuroepithelium and cerebellum have relatively high $\mathrm{HO}$ activity. This agrees with the finding that HO-2 is expressed abundantly in olfactory receptor neurons by in situ hybridization and immunohistochemistry (Ewing and Maines, 1992; Verma et al., 1993). These results indicate that brain has significant levels of heme (1.3 $\mathrm{nmol} / \mathrm{mg}$ protein) and high $\mathrm{HO}$ activity (280 pmol of bilirubin/mg protein per min), providing evidence for the physiological importance of heme function in neurons.

\section{Heme turnover and CO biosynthesis in olfactory receptor neurons}

In addition to heme and $\mathrm{HO}-2$, olfactory receptor neurons contain a high level of heme-metabolizing enzymes such as ALAS and cytochrome P-450 reductase (Verma et al., 1993). This suggests that heme metabolic turnover is significant in olfactory receptor neurons, providing us with an excellent model in which to study neuronal control of heme turnover and $\mathrm{CO}$ biosynthesis. Because the colocalization of ALAS with HO-2 in these neurons indicates that the machinery for porphyrin turnover and $\mathrm{CO}$ biosynthesis occur together, primary cultures of olfactory receptor neurons were incubated with $\left[2-{ }^{14} \mathrm{C}\right]$ glycine to label heme precursors, heme, and CO. As shown in Figure 1, cellular uptake of $\left[{ }^{14} \mathrm{C}\right] \mathrm{g}$ lycine and biosynthesis of $\left[{ }^{14} \mathrm{C}\right] \mathrm{ALA},\left[{ }^{14} \mathrm{C}\right]$ heme, and ${ }^{14} \mathrm{CO}$ were measured in these cell cultures at the indicated time intervals. All of these ${ }^{14} \mathrm{C}$-labeled heme precursors and metabolites increased in a similar manner over this time period.

The amounts labeled in $6 \mathrm{hr}$ were (in pmol/mg protein): 100 $\left[{ }^{14} \mathrm{C}\right]$ ALA, $5.3\left[{ }^{14} \mathrm{C}\right]$ heme, and $2.9{ }^{14} \mathrm{CO}$ (Table 2). Both unlabeled and ${ }^{14} \mathrm{C}$-labeled levels of cellular heme (the substrate of $\mathrm{HO}$ ) were measured in cultures to determine the specific activity of $\mathrm{CO}$ production. The total cellular heme was determined spectrophotometrically to be $1.5 \mathrm{nmol} / \mathrm{mg}$ protein (Table 2). Under the conditions used, incorporation of $\left[{ }^{14} \mathrm{C}\right]$ glycine into cellular heme increased over $6 \mathrm{hr}$, as shown in Figure $1 C$; the average concentration of $\left[{ }^{14} \mathrm{C}\right]$ heme during this period was $2.7 \mathrm{pmol} / \mathrm{mg}$ protein. As summarized in Table 2, the amount of total $\mathrm{CO}$ production was determined to be $1.6 \mathrm{nmol} / \mathrm{mg}$ protein per $6 \mathrm{hr}$, taking into account the ratio of total heme to $\left[{ }^{14} \mathrm{C}\right]$ heme. Similar adjustment for the dilution of $\left[{ }^{14} \mathrm{C}\right]$ glycine $(1.2 \mathrm{nmol} / \mathrm{mg}$ protein $)$ by endogenous free glycine $(20 \mathrm{nmol} / \mathrm{mg}$ protein; Hall et al., 1979; Freeman et al., 1983) yielded the following synthetic rates (in $\mathrm{nmol} / \mathrm{mg}$ protein per $6 \mathrm{hr}$ ): 3.4 for ALA, 180 for heme, and 95 for CO

Table 2. Total amount of $\mathrm{CO}$ production and heme turnover in olfactory receptor neuron

\begin{tabular}{|c|c|c|c|c|c|}
\hline \multirow[b]{2}{*}{$\begin{array}{l}\text { Heme precursors } \\
\text { and metabolites }\end{array}$} & \multicolumn{3}{|c|}{ Labeling with $\left[{ }^{14} \mathrm{C}\right]$ glycine } & \multicolumn{2}{|c|}{ Labeling with $\left[{ }^{3} \mathrm{H}\right] \mathrm{ALA}$} \\
\hline & $\begin{array}{l}{ }^{14} \text { C-labeled } \\
\text { products } \\
(\mathrm{pmol} / \mathrm{mg} \mathrm{p}\end{array}$ & $\begin{array}{l}\text { Total amount } \\
\text { hr) }\end{array}$ & $\begin{array}{l}\text { Newly synthesized } \\
\text { amount from glycine }{ }^{a}\end{array}$ & $\begin{array}{l}{ }^{3} \mathrm{H} \text {-labeled } \\
\text { products } \\
(\mathrm{pmol} / \mathrm{mg} \mathrm{p}\end{array}$ & $\begin{array}{l}\text { Total amount } \\
6 \mathrm{hr})\end{array}$ \\
\hline Glycine & 1,200 & & & & \\
\hline ALA & 100 & & 3400 & 36 & \\
\hline Heme & 5.3 & $1500^{b}$ & 180 & 1.2 & $1,500^{b}$ \\
\hline $\mathrm{CO}$ & 2.9 & $1600^{c}$ & 95 & & \\
\hline Bilirubin & & & & 0.23 & $570^{c}$ \\
\hline
\end{tabular}

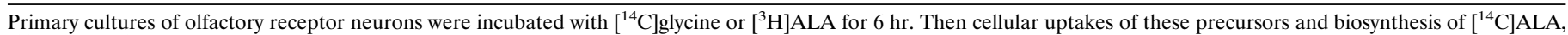
$\left[{ }^{14} \mathrm{C}\right]$ heme, ${ }^{14} \mathrm{CO},\left[{ }^{3} \mathrm{H}\right]$ heme, and $\left[{ }^{3} \mathrm{H}\right]$ bilirubin were measured in these cell cultures.

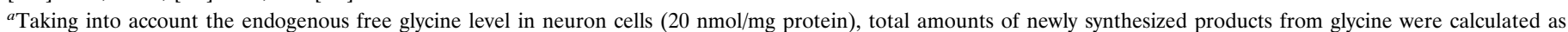
described below. Average concentration of cellular $\left[{ }^{14} \mathrm{C}\right]$ glycine was $600 \mathrm{pmol} / \mathrm{mg}$ protein.

$$
\text { Newly synthesized amount from glycine }={ }^{14} \mathrm{C} \text {-labeled amount } \times(\text { total glycine }) /\left(\text { average }\left[{ }^{14} \mathrm{C}\right] \text { glycine }\right)
$$

${ }^{b}$ The cellular heme concentration was determined spectrophotometrically and expressed as pmol/mg protein.

${ }^{c}$ The total amount of production was calculated as described below. 

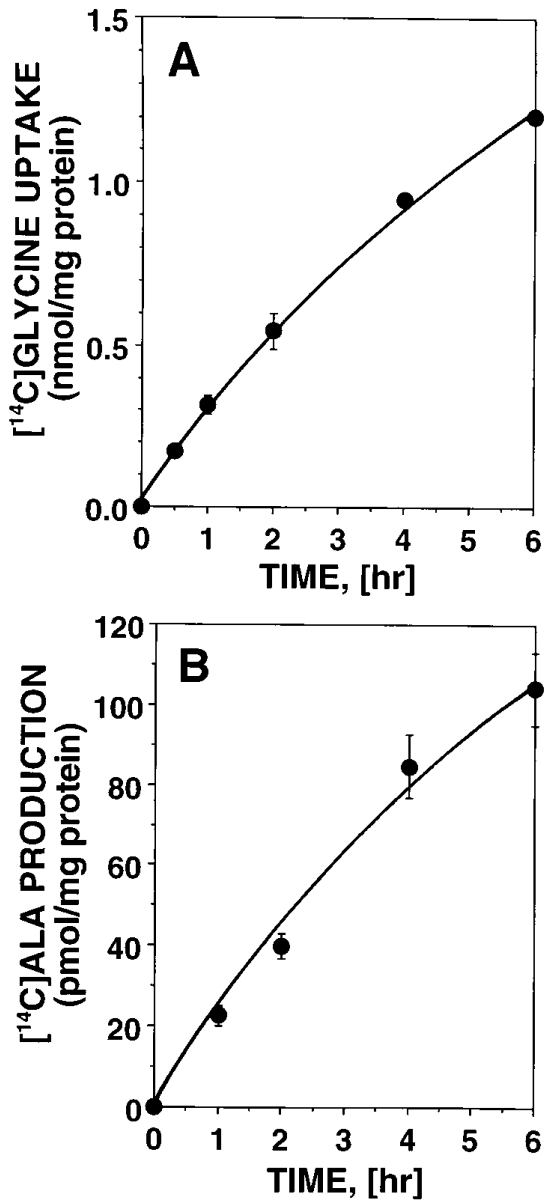
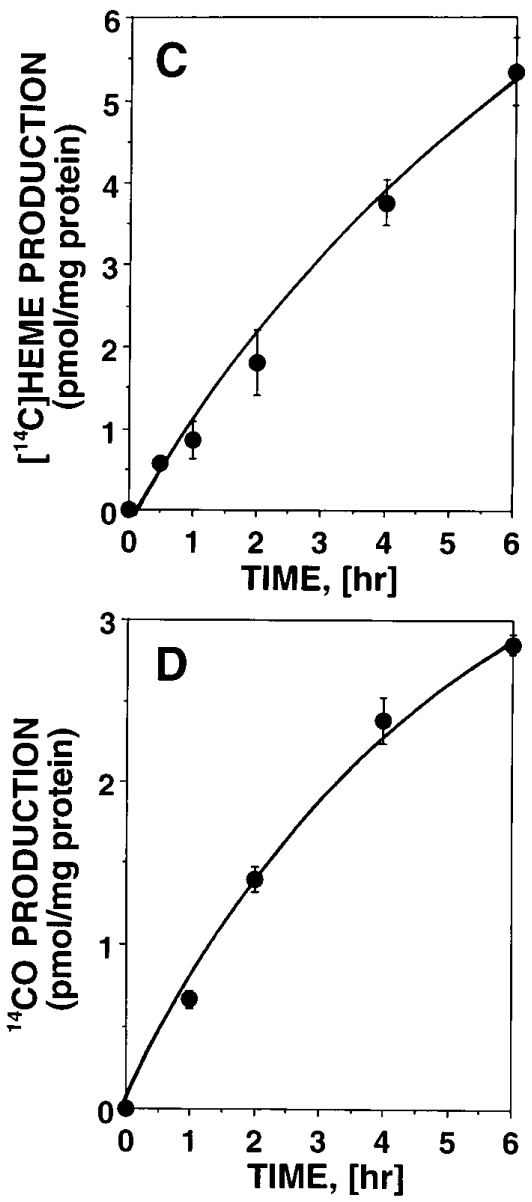

Figure 1. Cellular uptake of $\left[{ }^{14} \mathrm{C}\right]$ glycine and biosynthesis of ${ }^{14} \mathrm{C}$-labeled heme precursors and metabolites from $\left[{ }^{14} \mathrm{C}\right]$ glycine in primary cultures of olfactory receptor neurons. Primary cultures of olfactory receptor neurons were prepared from neonatal rats as described previously and used for this experiment on culture day 3 . Cultures in the well plates were incubated with $\left[2-{ }^{14} \mathrm{C}\right]$ glycine for $6 \mathrm{hr}$. At indicated time intervals, cellular uptake of $\left[2-{ }^{14} \mathrm{C}\right]$ glycine $(A)$ and the ${ }^{14} \mathrm{C}$-radioactivities incorporated into $\left[{ }^{14} \mathrm{C}\right] \mathrm{ALA}(B),\left[{ }^{14} \mathrm{C}\right]$ heme $(C)$, and ${ }^{14} \mathrm{CO}(D)$ were measured as described in Materials and Methods. Data are presented as the mean of two to four independent experimental determinations. determined by thin-layer chromatography. The ratio of $\left[{ }^{3} \mathrm{H}\right]$ heme to $\left[{ }^{3} \mathrm{H}\right] \operatorname{ALA}(1.2 / 36=3.3 \%)$ in this experiment is equivalent statistically to that of $\left[{ }^{14} \mathrm{C}\right]$ heme to $\left[{ }^{14} \mathrm{C}\right] \mathrm{ALA}(5.3 / 100=5.3 \%)$, which confirms the rate of the cellular heme synthetic pathway in Table 2. Taking into account the ratio of total heme to $\left[{ }^{3} \mathrm{H}\right]$ heme, we determined the amount of total bilirubin production to be 0.57 $\mathrm{nmol} / \mathrm{mg}$ protein per $6 \mathrm{hr}$, a value of similar magnitude to that obtained for the total $\mathrm{CO}$ production calculated from ${ }^{14} \mathrm{CO}$ measurement $(1.6 \mathrm{nmol} / \mathrm{mg}$ protein per $6 \mathrm{hr})$. Thus, these two ap-
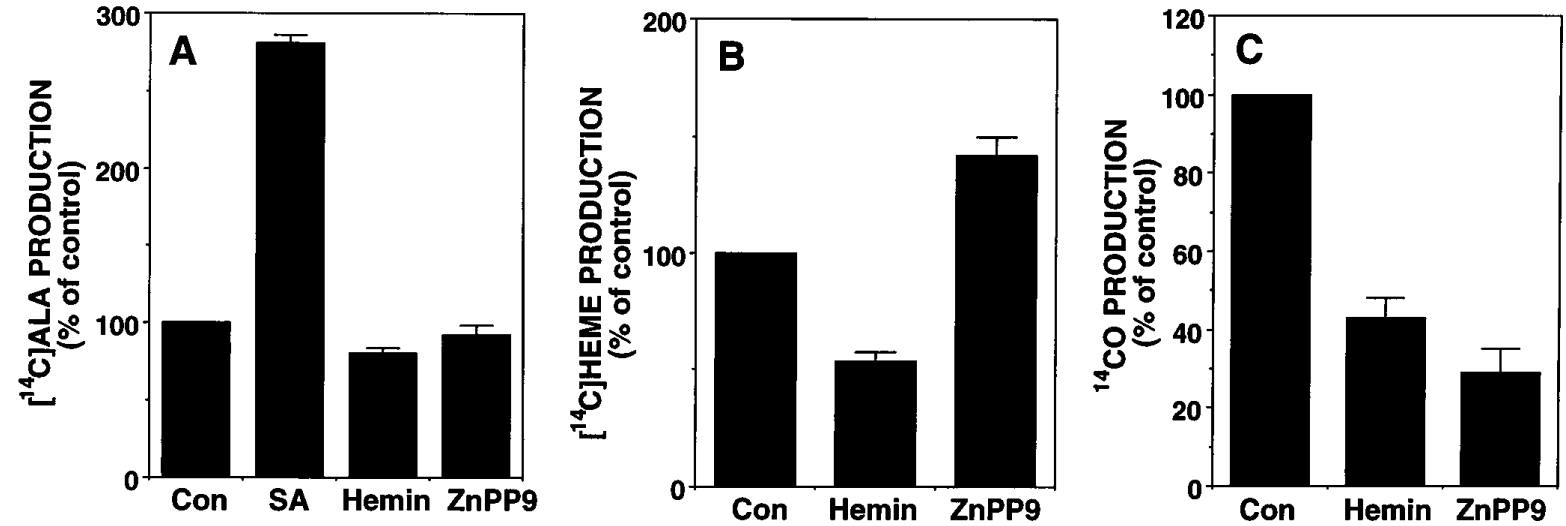

Figure 2. Negative feedback regulation of heme metabolism and effect of inhibitors on the metabolic pathway in primary cultures of olfactory receptor neurons. Primary cultures of olfactory receptor neurons were incubated with $\left[{ }^{14} \mathrm{C}\right]$ glycine in the presence or absence of hemin $(50 \mu \mathrm{M})$, SA $(1 \mathrm{mM})$, and ZnPP9 $(10 \mu \mathrm{M})$. After $6 \mathrm{hr}$, the biosynthesis of $\left[{ }^{14} \mathrm{C}\right] \mathrm{ALA}(A)$, $\left[{ }^{14} \mathrm{C}\right]$ heme $(B)$, and ${ }^{14} \mathrm{CO}(C)$ were determined as described in Materials and Methods. Data are presented as the mean of two to three independent experimental determinations \pm SEM. 


\section{SUCCINYL-CoA \\ GLYCINE}

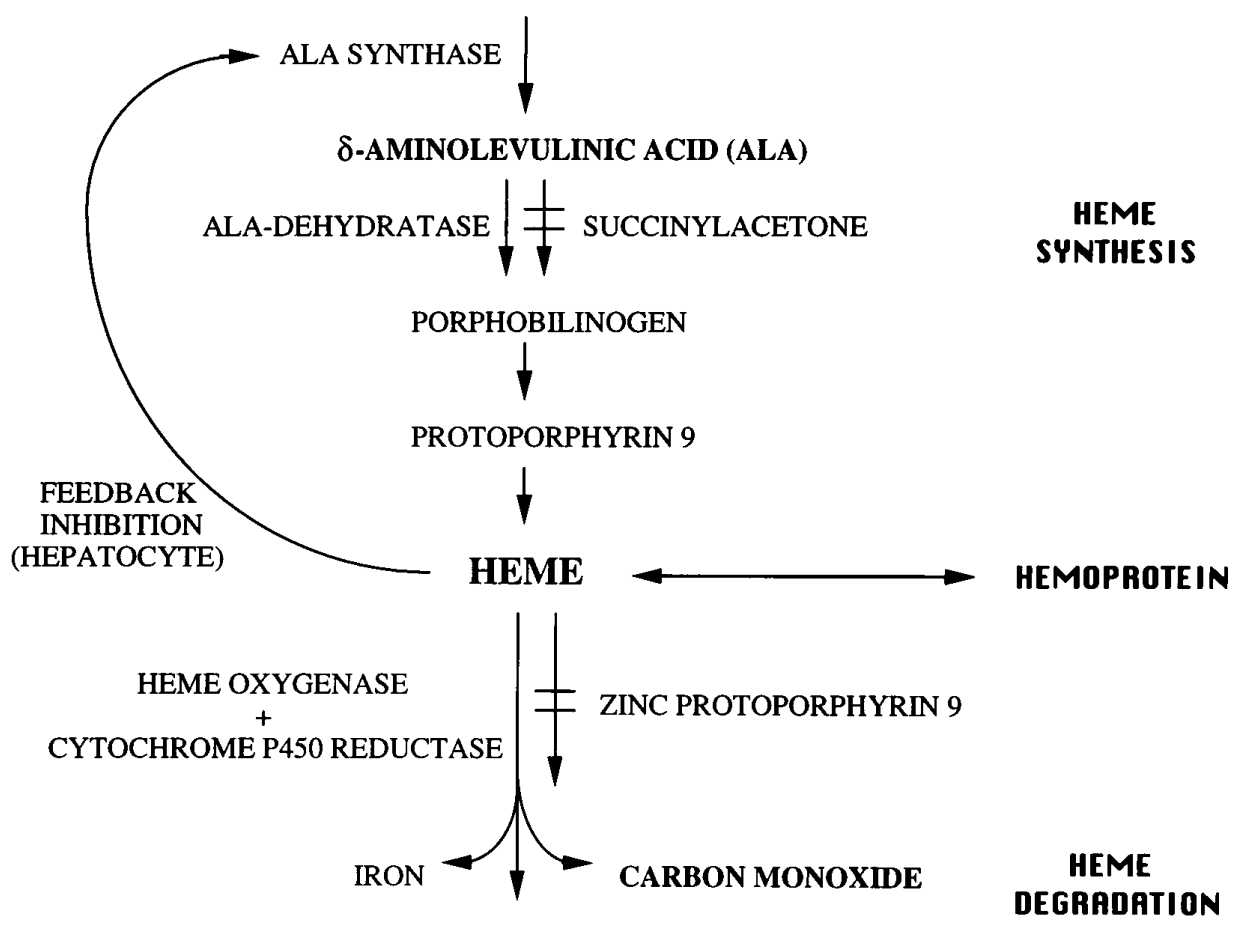

BILIVERDIN

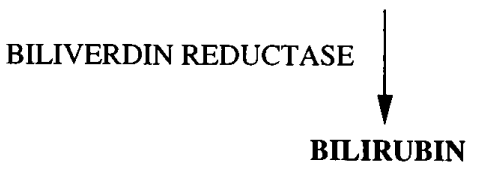

Figure 3. Pathway, regulation, and inhibitors of heme metabolism. The first enzyme of the heme biosynthetic pathway, ALAS is the ratecontrolling enzyme of this pathway. Heme formation is subject to end-product regulation by negative feedback, but the exact point of metabolic control differs between hepatocytes and erythroid cells. In the liver, ALAS is regulated negatively by heme, the end product of the pathway. In contrast, in erythroid cells, ALAS is not under the same regulatory mechanism. $\mathrm{HO}$ is the rate-controlling enzyme of the heme degradation pathway. SA is a potent inhibitor of ALA dehydratase activity. $\mathrm{ZnPP} 9$ is a potent inhibitor of $\mathrm{HO}$ activity. proaches for measurement of metabolic labeling yielded comparable results. These studies verify that endogenous heme synthesis is significant in neurons.

\section{Regulation of heme metabolism by exogenous heme and inhibitors}

Heme formation is subject to end-product regulation by negative feedback, but the exact point of metabolic control differs between tissues (May and Bawden, 1989). As shown in Figure 3, studies in liver culture provided strong evidence that the rate-limiting enzyme of the heme biosynthetic pathway, ALAS, is regulated by heme, the end product of the pathway (Granick, 1966; Granick et al., 1975). To investigate the regulatory mechanism of heme in olfactory receptor neurons, we incubated primary cultures of olfactory receptor neurons with $\left[{ }^{14} \mathrm{C}\right]$ glycine in the presence or absence of exogenous heme or inhibitors of this pathway (Fig. 3). As shown in Figure $2 B, 50 \mu \mathrm{M}$ of hemin inhibited $\left[{ }^{14} \mathrm{C}\right]$ heme synthesis to $54 \%$ of control, which indicates the existence of a negative feedback system in olfactory receptor neurons. However, $50 \mu \mathrm{M}$ hemin had little inhibitory effect on the incorporation of $\left[{ }^{14} \mathrm{C}\right]$ glycine into cellular ALA in this neuron culture (Fig. 2A), although hemin concentrations lower than $50 \mu \mathrm{M}$ repressed the ALAS activity to $50 \%$ of control in liver cell cultures (Granick et al., 1975).

These results indicate that hemin regulates the heme synthetic pathway in neurons, not at the level of ALAS but at other sites. One mm succinyl acetone (SA) clearly elevated cellular $\left[{ }^{14} \mathrm{C}\right] \mathrm{ALA}$ level to $280 \%$ of control (Fig. $2 A$ ), which agrees with its potent inhibitory effect on ALA dehydratase. ZnPP9 (10 $\mu \mathrm{M})$, a potent inhibitor of $\mathrm{HO}$ activity, had a significant inhibitory effect on ${ }^{14} \mathrm{CO}$ production and elevated $\left[{ }^{14} \mathrm{C}\right]$ heme level to $140 \%$ of control (Fig. $2 B, C)$. However, the same concentration of $\mathrm{ZnPP} 9$ had little effect on cellular $\left[{ }^{14} \mathrm{C}\right]$ ALA levels (Fig. $2 A$ ). Although $50 \mu \mathrm{M}$ of hemin significantly suppressed ${ }^{14} \mathrm{CO}$ production, this may be attributable to its competitive effect on $\left[{ }^{14} \mathrm{C}\right]$ heme (substrates) binding to $\mathrm{HO}$ (enzyme) rather than by direct inhibition of HO.

\section{Regulation of heme turnover in neuronal differentiation}

To investigate the change of heme turnover during growth and differentiation of olfactory receptor neurons, we determined the effects of neuronal maturation and TGF- $\beta 2$ (an olfactory neurogenic/survival factor) on heme biosynthesis and degradation in cultures over time as cells matured. Olfactory receptor neurons were cultured in the presence or absence of $10 \mathrm{ng} / \mathrm{ml} \mathrm{TGF}-\beta 2$ from days 1 to 5 . On each day, cultures were incubated with $\left[{ }^{14} \mathrm{C}\right]$ glycine to label heme. At $6 \mathrm{hr}$ after addition of $\left[{ }^{14} \mathrm{C}\right]$ glycine, $\left[{ }^{14} \mathrm{C}\right]$ heme was measured in these neuronal cultures. As shown in Figure $4 A$, there was an increase of $\left[{ }^{14} \mathrm{C}\right]$ heme production, from $1.2 \mathrm{pmol} / \mathrm{mg}$ protein at day 1 in culture to $3.0 \mathrm{pmol} / \mathrm{mg}$ protein at day 3 . Afterward, $\left[{ }^{14} \mathrm{C}\right]$ heme production fell until day 5. Whereas TGF- $\beta 2$ potentiated the increase of $\left[{ }^{14} \mathrm{C}\right]$ heme production at day 3 , it potentiated the decrease of $\left[{ }^{14} \mathrm{C}\right]$ heme production at days 4 and 5 .

The level of $\mathrm{HO}$ expression was determined by measuring the level of HO-2 mRNA in culture on each culture day. As shown in Figure $4 B$, HO-2 mRNA is expressed abundantly during the 
A

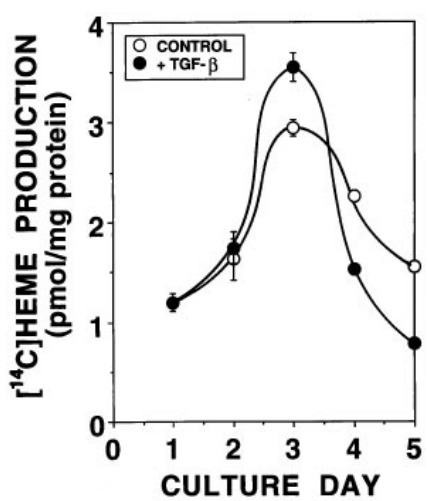

B
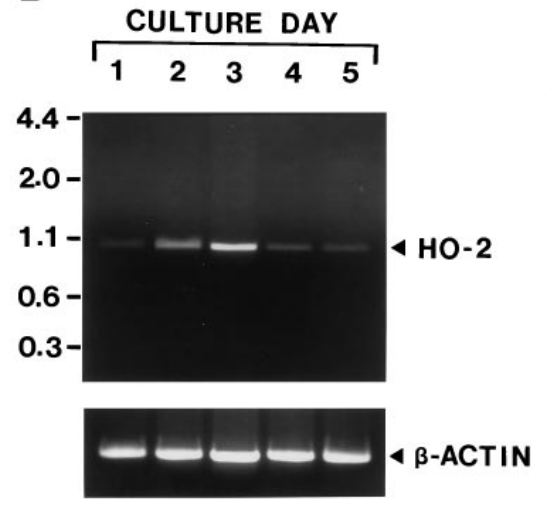

C CULTURE DAY
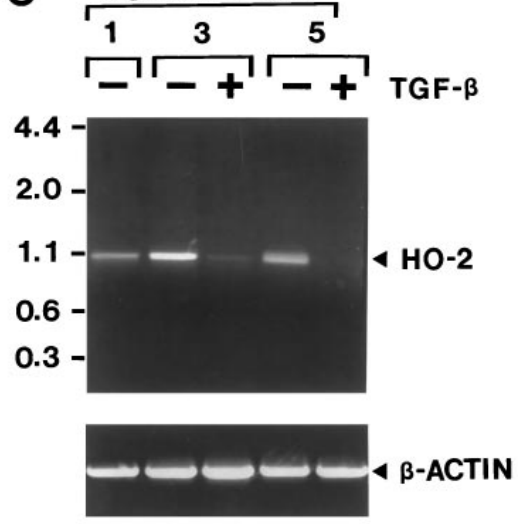

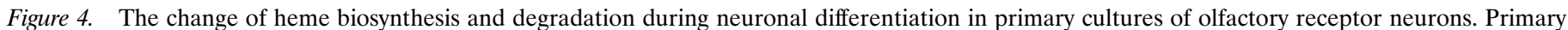

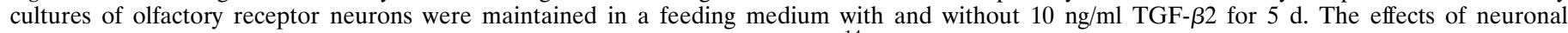

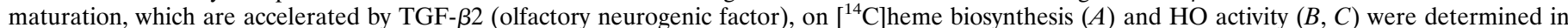

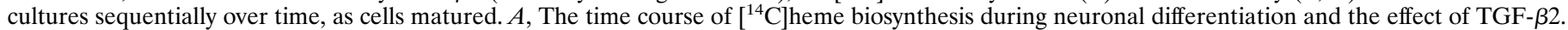

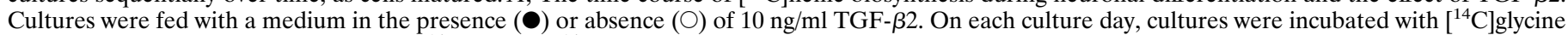

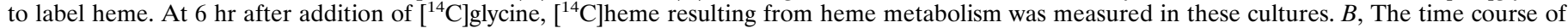

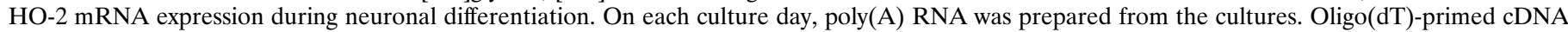

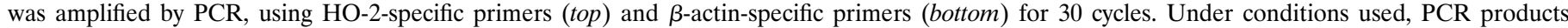

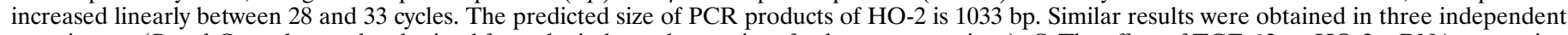

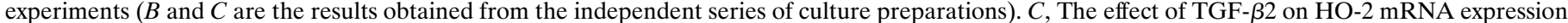

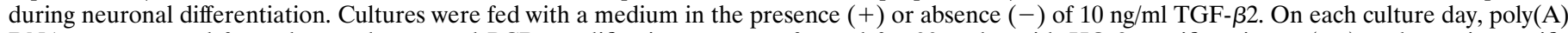

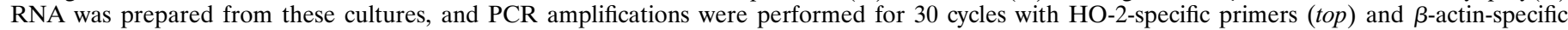
primers (bottom). The same results were repeated in two independent experiments.

early phase of culture (days 2 and 3 ) with the highest concentration at day 3 , identical to the changes in $\left[{ }^{14} \mathrm{C}\right]$ heme production in culture. TGF- $\beta 2$ consistently suppressed the expression of HO-2 in culture at days 3 and 5 (Fig. $4 C$ ). Although TGF- $\beta 2$ elevated $\left[{ }^{14} \mathrm{C}\right]$ heme levels at day 3 , this effect may be attributable to its potent inhibitory effect on HO-2 expression rather than to a change in heme synthetic rate. These findings indicate that both heme biosynthesis and degradation are enhanced significantly during the immature stages of culture and that, as neuronal maturation occurs, heme biosynthesis and degradation are coordinately down-regulated, further confirming that these activities are important in neurons.

\section{Effect of physiological level of exogenous $\mathrm{CO}$ on cGMP level}

Like NO, CO binds to the iron of the heme moiety in soluble guanylyl cyclase to activate this enzyme (Brüne and Ullrich, 1987; Furchgott and Jothianandan, 1991; Kharitonov et al., 1995). However, the potency of $\mathrm{CO}$ as a guanylyl cyclase activator is weaker, raising the question as to whether $\mathrm{CO}$ could have any effect on soluble guanylyl cyclase at physiological concentrations (Stone and Marletta, 1994). As shown in Table 2, the total amount of CO production was determined to be $1.6 \mathrm{nmol} / \mathrm{mg}$ protein per $6 \mathrm{hr}$. Because of the gaseous nature of $\mathrm{CO}$ and its high affinity for hemoprotein, it is very difficult to determine the exact intracellular concentration of $\mathrm{CO}$. However, taking into account the diffusion of $\mathrm{CO}$, it may be reasonable to assume that the amount of $\mathrm{CO}$ produced for 10-30 min is an effective concentration in the cell. On this assumption, the endogenous $\mathrm{CO}$ level was calculated to be $50-160 \mathrm{pmol} / \mathrm{mg}$ protein or $10-30 \mu \mathrm{M}$. To investigate whether this physiological level of $\mathrm{CO}$ can affect guanylyl cyclase activity, we examined the effect of $\mathrm{CO}$ at various concentrations on soluble guanylyl cyclase activation (Fig. 5). CO (10-30 $\mu \mathrm{M})$, which corre- sponds to endogenous CO levels, significantly elevated guanylyl cyclase activity up to $190-220 \%$ of control. This result, together with the chemical stability of $\mathrm{CO}$, suggests that $\mathrm{CO}$ does not work as a rapid stimulator of cGMP but, rather, works as a modulator that could produce slower, long-term effects.

\section{DISCUSSION}

There are several major findings of the present study. (1) Quantitative analysis has demonstrated that high levels of heme synthesis and $\mathrm{CO}$ production occur in olfactory receptor neurons,

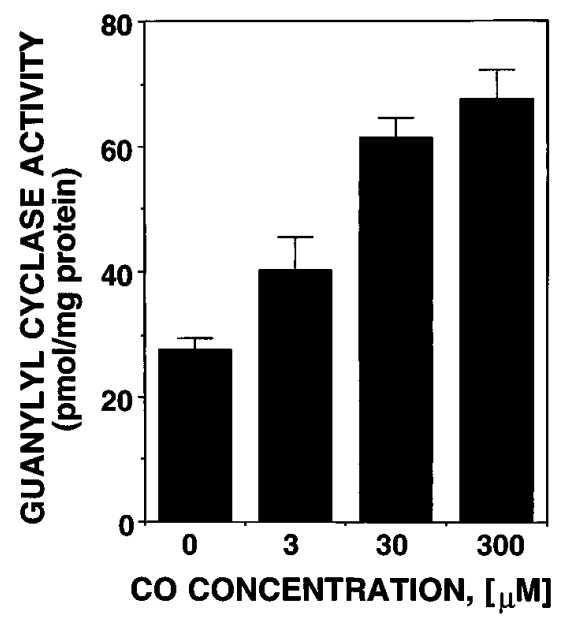

Figure 5. Effects of exogenous $\mathrm{CO}$ on the activity of soluble guanylyl cyclase. Soluble guanylyl cyclase was prepared as a $100,000 \times g$ supernatant fraction from rat brain. The guanylyl cyclase activity was assayed in the presence of varying concentrations of exogenous $\mathrm{CO}$ as described in Materials and Methods. Data are presented as the mean of two to three independent experimental determinations. 
consistent with its postulated role as a neurotransmitter. (2) The regulation of heme biosynthesis in this neuron is subject to negative feedback regulation at a site different from that in liver, consistent with the hypothesis that $\mathrm{HO}$ does not function simply in heme degradation in neurons. (3) Heme synthesis and degradation are enhanced during immature stages of neuronal development in culture and are suppressed during the mature stage. (4) The total amount of $\mathrm{CO}$ that is produced physiologically by this neuron is clearly enough to activate guanylyl cyclase.

A necessary prerequisite for a functional role of $\mathrm{CO}$ as a neuronal messenger is the significant expression of heme and heme metabolic enzymes in the nervous system. For this reason, we measured the levels of cellular heme and $\mathrm{HO}$ activity in spleen, liver, and the nervous system. Although $\mathrm{HO}$ has been detected in all tissues, the relative abundance of $\mathrm{HO}$ varies greatly among different sources (Maines, 1988). Hemoglobin heme from senescent red blood cells is degraded mainly by the phagocytic cells that line the sinusoids of the spleen, liver, and bone marrow. Therefore, $\mathrm{HO}$ activity of these tissues is $>10$-fold higher than that of other HO-poor tissues, such as the small intestine (Maines, 1988). $\mathrm{HO}$ activity in brain was high and equivalent to that of liver, and it colocalized with significant levels of cellular heme there, which suggests active local heme synthesis and turnover. As a result, we attempted to elucidate the mechanism and role of this heme turnover and resultant $\mathrm{CO}$ production in the nervous system, which had been unclear.

In animal cells the regulation of the heme biosynthetic pathway differs between erythroid and nonerythroid tissues (May and Bawden, 1989). In the liver and other nonerythroid cells, the rate of heme biosynthesis is controlled by the level of ALAS (Ponka and Schulman, 1985). Heme may regulate its own synthesis by feedback inhibition of ALAS and by controlling the synthesis of ALAS. In contrast, it is now generally agreed that ALAS is not under the same regulatory mechanism in differentiating erythroid cells (Granick and Sassa, 1978; Ponka and Schulman, 1985; Gardner and Cox, 1988), but at present there is no clear consensus as to what and how many factors may limit heme production. Our results demonstrate that the regulatory mechanism of heme biosynthesis by olfactory receptor neurons is similar to that in the erythroid cell type, in which degradation is not the primary goal. In olfactory receptor neurons, exogenous heme clearly suppressed heme biosynthesis, which indicates that the overall rate of heme synthesis in this cell is subject to negative feedback control. However, exogenous heme did not affect ALAS activity, suggesting that the action site of this negative feedback control is not at the level of ALAS. This is the first evidence that neurons are able to regulate heme synthesis by a mechanism similar to that of erythroid cells, and this process of regulation may be applicable to other types of neurons.

SA significantly inhibited ALA dehydratase activity in olfactory receptor neurons, which resulted in the accumulation of ALA. SA is an abnormal metabolite produced in patients with hereditary tyrosinemia as a consequence of an inherited deficiency of fumaryl acetate hydrolase (Sassa and Kappas, 1983). Because SA is an extremely potent inhibitor of ALA dehydratase, patients with this disease excrete excessive amounts of urinary ALA and have low ALA dehydratase activity in erythrocytes and liver. Neurological dysfunction is one of the clinical manifestations of this disorder. Together with this background, our results confirm the potent inhibitory effect of SA on ALA dehydratase in the nervous system and implicate the physiological importance of heme metabolism in neuronal function.
It has now been shown that, in cultured primary olfactory receptor neurons, both formation and degradation of heme are enhanced in the immature stages of neuron culture, after which they progressively declined as the neurons matured. It has becoming increasingly evident that heme synthesis and degradation play pivotal roles in the regulation of growth and differentiation of erythroid and nonerythroid cells (Abraham, 1991). During erythropoietic differentiation one of the key events is the increase in the synthesis of heme for hemoglobin production. The vital, ubiquitous role of heme in mammalian physiology is attested to by its function as the prosthetic group in a variety of important hemoproteins. However, the effect of heme on erythropoiesis is distinct from its direct involvement as a prosthetic group. The expression of specific heme metabolic enzymes determines the level of cellular heme that is necessary for proper erythropoiesis (Sassa et al., 1975; Conder et al., 1991). The heme metabolic enzymes participate in the implementation of both stimulation and suppression of erythropoiesis. Enhancement of erythropoiesis obtained with erythropoietin and some growth factors results in increased levels of ALAS and porphobilinogen deaminase, the proposed rate-limiting enzymes in the heme biosynthetic pathway. Suppression of erythropoiesis is observed by either insufficient levels of one of the heme biosynthetic enzymes or by increased heme degradation.

In hematopoietic cells, HO level may play a crucial role during stem cell proliferation and differentiation (Abraham, 1991). In human in vitro erythroid colony development systems, HO activity was elevated in the early phases of erythroid culture, after which it declined. A similar observation was made in olfactory receptor neurons and in cerebellar granule cell cultures. A decrement in HO activity may be an important feature of the differentiation process. In human erythroleukemia cells, the inducers of differentiation, such as heme, cause a repression in $\mathrm{HO}$ activity and concomitant appearance of staining (Abraham, 1991). TGF- $\beta 2$ is known to be an olfactory neurogenic/survival factor that initiates terminal differentiation in olfactory receptor neurons (Mahanthappa and Schwarting, 1993). In olfactory receptor neuron cultures, TGF- $\beta 2$ caused an increase in neuron cell adhesion molecule (N-CAM)-positive cells; N-CAM is a marker of olfactory neurogenesis. In our data, TGF- $\beta 2$ significantly suppressed the expression of HO-2 at the phases of neuronal differentiation in culture. This result agrees with the report that TGF- $\beta 2$ suppressed CO production in olfactory receptor neuron (Ingi and Ronnett, 1995). These lines of evidence suggest that the repression of HO in neurons and erythroid cells may work as a trigger of the differentiation of these cells.

$\mathrm{CO}$ is a weak activator of soluble guanylyl cyclase. In vitro, $\mathrm{CO}$ activation of purified soluble guanylyl cyclase is $1 / 30$-fold less potent than NO (Stone and Marletta, 1994). Therefore, it was questioned whether $\mathrm{CO}$ will have any effect on soluble guanylyl cyclase at physiological concentration. As shown in Figure 5, 3-30 $\mu \mathrm{M} C \mathrm{C}$ actually activated soluble guanylyl cyclase significantly. These results suggest that $\mathrm{CO}$ can affect guanylyl cyclase activity effectively in the range of 3-30 $\mu \mathrm{M}$ and agree with the recent report that $\mathrm{CO}$ regulates cyclic nucleotide-gated channels via cGMP formation with a $K_{1 / 2}$ value of $2.9 \mu \mathrm{M}$ in olfactory receptor neurons (Leinders-Zufall et al., 1995). Although NO can work as a very potent and short-lived stimulator of cGMP, the chemical stability of CO may have the advantage of working as a modulator that could produce long-term or tonic effects. $\mathrm{CO}$ may serve as a neuromodulator that produces long-term effects on cGMP level in the nervous system. It has been proposed that $\mathrm{CO}$, either alone or 
in combination with $\mathrm{NO}$, may act as a retrograde messenger that produces activity-dependent enhancement of synaptic transmission during long-term potentiation in the hippocampus (Stevens and Wang, 1993; Zhuo et al., 1993). By altering the cyclic nucleotide-gated channel activity via changes in the level of cGMP, CO may modulate the excitable properties of olfactory receptor neurons (Leinders-Zufall et al., 1995).

Although the amplitude of $\mathrm{CO}$ induced-activation of soluble guanylyl cyclase is not so drastic (approximately two- to threefold), the action of CO may be more complicated than the simple activation of this enzyme. Recently, we have observed that, in the presence of NO, low micrometers of $\mathrm{CO}$ actually suppressed NO-mediated activation of soluble guanylyl cyclase in cerebellar granule cells (Ingi et al., 1996). Collectively, these results indicate that the level of $\mathrm{CO}$ produced by olfactory receptor neurons is significant enough to work as a regulator of cGMP levels in the nervous system.

\section{REFERENCES}

Abraham NG (1991) Molecular regulation-biological role of heme in hematopoiesis. Blood 5:19-28.

Blanckaert N (1980) Analysis of bilirubin and bilirubin mono- and diconjugates. Biochem J 185:115-128.

Brüne B, Ullrich V (1987) Inhibition of platelet aggregation by carbon monoxide is mediated by activation of guanylate cyclase. Mol Pharmacol 32:497-504.

Conder LH, Woodard SI, Dailey HA (1991) Multiple mechanisms for the regulation of haem synthesis during erythroid cell differentiation. Biochem J 275:321-326.

Cruse I, Maines MD (1988) Evidence suggesting that the two forms of heme oxygenase are products of different genes. J Biol Chem 263:3348-3353.

Ebert PS, Tschudy DP, Choudhry JN, Chirigos MA (1970) A simple micro method for the direct determination of $\delta$-amino $\left[{ }^{14} \mathrm{C}\right]$ levulinic acid production in murine spleen and liver homogenates. Biochim Biophys Acta 208:236-250.

Ewing JF, Maines MD (1992) In situ hybridization and immunohistochemical localization of heme oxygenase- 2 mRNA and protein in normal rat brain: differential distribution of isozyme 1 and 2 cell. Mol Cell Neurosci 3:559-570.

Falk JE (1975) Protohemin. In: Porphyrins and metalloporphyrins (Smith KM, ed), p 808. Amsterdam: Elsevier Scientific.

Freeman ME, Lane JD, Smith JE (1983) Turnover rates of amino acid neurotransmitters in regions of rat cerebellum. $J$ Neurochem 40:1441-1447.

Furchgott RF, Jothianandan D (1991) Endothelium-dependent and independent vasodilatation involving cyclic GMP: relaxation induced by nitric oxide, carbon monoxide, and light. Blood Vessels 28:52-61.

Gardner LC, Cox TM (1988) Biosynthesis of heme in immature erythroid cells. J Biol Chem 263:6676-6682.

Gardner LC, Smith SJ, Cox TM (1991) Biosynthesis of $\delta$-aminolevulinic acid and the regulation of heme formation by immature erythroid cells in man. J Biol Chem 266:22010-22018.

Granick JL, Sassa S (1978) Hemin control of heme biosynthesis in mouse friend virus-transformed erythroleukemia cells in culture. J Biol Chem 253:5402-5406.

Granick S (1966) The induction in vitro of the synthesis of $\delta$-aminolevulinic acid synthetase in chemical porphyria: a response to certain drugs, sex hormones, and foreign chemicals. J Biol Chem 241:1359-1375.

Granick S, Sinclair P, Sassa S, Grieninger G (1975) Effects by heme, insulin, and serum albumin on heme and protein synthesis in chick embryo liver cells cultured in a chemically defined medium and a spectrofluorometric assay for porphyrin composition. J Biol Chem 250:9215-9225.
Hall PV, Smith JE, Lane J, Mote TBA, Campbell R (1979) Glycine and experimental spinal spasticity. Neurology 29:262-267.

Ingi T, Ronnett GV (1995) Direct demonstration of a physiological role for carbon monoxide in olfactory receptor neurons. J Neurosci 15:8214-8222.

Ingi T, Cheng J, Ronnett GV (1996) Carbon monoxide: an endogenous modulator of the nitric oxide-cyclic GMP signaling system. Neuron $16: 835-842$.

Kharitonov VG, Sharma VS, Pilz RB, Magde D, Koesling D (1995) Basis of guanylate cyclase activation by carbon monoxide. Proc Natl Acad Sci USA 92:2568-2571.

Labbe RF, Nishida G (1957) A new method of hemin isolation. Biochim Biophys Acta 26:437.

Leinders-Zufall T, Shepherd GM, Zufall F (1995) Regulation of cyclic nucleotide-gated channels and membrane excitability in olfactory receptor cells by carbon monoxide. J Neurophysiol 74:1498-1508.

Lincoln BC, Aw TY, Bonkovsky HL (1989) Heme catabolism in cultured hepatocytes: evidence that heme oxygenase is the predominant pathway and that a proportion of synthesized heme is converted rapidly to biliverdin. Biochim Biophys Acta 992:49-58.

Mahanthappa NK, Schwarting GA (1993) Peptide growth factor control of olfactory neurogenesis and neuron survival in vitro: roles of EGF and TGF- $\beta$ s. Neuron 10:293-305.

Maines MD (1988) Heme oxygenase: function, multiplicity, regulatory mechanisms, and clinical applications. FASEB J 2:2557-2568.

May BK, Bawden MJ (1989) Control of heme biosynthesis in animals. Semin Hematol 26:150-156.

Nathanson JA, Scavone C, Scanlon C, McKee M (1995) The cellular $\mathrm{Na}^{+}$ pump as a site of action for carbon monoxide and glutamate: a mechanism for long-term modulation of cellular activity. Neuron 14:781-794.

Nudel U, Zakut R, Shani M, Neuman S, Levy Z, Yaffe D (1983) The nucleotide sequence of the rat cytoplasmic $\beta$-actin gene. Nucleic Acids Res 11:A1759-A1760.

Ponka P, Schulman HM (1985) Regulation of heme synthesis in erythroid cells: hemin inhibits transferrin iron utilization but not protoporphyrin synthesis. Blood 65:850-857.

Prabhakar NR, Dinerman JL, Agani FH, Snyder SH (1995) Carbon monoxide: a role in carotid body chemoreception. Proc Natl Acad Sci USA 92:1994-1997.

Ronnett GV, Hester LD, Snyder SH (1991) Primary culture of neonatal rat olfactory neurons. J Neurosci 11:1243-1255.

Rotenberg MO, Maines MD (1988) Isolation, characterization, and expression in Escherichia coli of a cDNA encoding rat heme-oxygenase-2. J Biol Chem 263:3348-3353.

Sassa S, Kappas A (1983) Hereditary tyrosinemia and the heme biosynthetic pathway. J Clin Invest 71:625-634.

Sassa S, Granick S, Chang C, Kappas A (1975) Induction of enzymes of the heme biosynthetic pathway in friend leukemia cells in culture. In: Erythropoiesis (Nakao K, Fisher JW, Takaku F, eds), pp 383-396. Tokyo: University of Tokyo.

Schacter BA (1978) Assay of microsomal heme oxygenase in liver and spleen. Methods Enzymol 52:367-372.

Stevens CF, Wang Y (1993) Reversal of long-term potentiation by inhibitors of haem oxygenase. Nature 364:147-148.

Stone JR, Marletta MA (1994) Soluble guanylate cyclase from bovine lung: activation with nitric oxide and carbon monoxide and spectral characterization of the ferrous and ferric states. Biochemistry 33:5636-5640.

Tenhunen R, Marver HS, Schmid R (1970a) The enzymatic catabolism of hemoglobin: stimulation of microsomal heme oxygenase by hemin. J Lab Clin Med 75:410-421.

Tenhunen R, Ross ME, Marver HS, Schmid R (1970b) Reduced nicotinamide-adenine dinucleotide phosphate-dependent biliverdin reductase: partial purification and characterization. Biochemistry 9:298-303.

Verma A, Hirsch DJ, Glatt C, Ronnett GV, Snyder SH (1993) Carbon monoxide: a putative neural messenger. Science 259:381-384.

Zhuo M, Small SA, Kandel ER, Hawkins RD (1993) Nitric oxide and carbon monoxide produce activity-dependent long-term synaptic enhancement in hippocampus. Science 260:1946-1950. 